\title{
DEVELOPMENT IN LATIN AMERICA, ORIGINS AND ACTUALITY OF FOUR LINES OF INTERPRETATION ${ }^{1}$
}

\author{
DESENVOLVIMENTO NA AMÉRICA LATINA, ORIGENS E ATUALIDADE DE \\ QUATRO LINHAS DE INTERPRETAÇÃO
}

DOI: $10.5380 /$ cg.V10i2. 78168

\author{
Ricardo Bruno Boff 2
}

\begin{abstract}
Latin America, despite its immensity and diversity, has a common thread in its history, which causes waves of similar events, from time to time, that spread across the continent. The thought about development models produced in the region, which guides the leaderships of the countries, influences and is influenced by these historical waves, spreading with them. In this article, the main objective was to discuss the origins and actuality of four major lines of Latin American thought on development - national-developmentalism, revolutionaryMarxism, neoliberalism, and decolonialism. From this, a brief presentation of each one was made, locating their origins and pointing out their main characteristics and current relevance. In the end, it was possible to verify that, despite the richness of the debate on development in Latin America, it is necessary to renew the old matrixes and advance in the new ones, given the limitations they present.
\end{abstract}

Keywords: Latin America; Development; Latin-American thought.

\section{Resumo}

A América Latina, apesar de sua imensidão e diversidade, guarda um fio condutor na sua história, o qual faz com que ondas de acontecimentos semelhantes, de tempos em tempos, se espalhem pelo continente. $\mathrm{O}$ pensamento sobre modelos de desenvolvimento produzido na região, que orienta as lideranças dos países, influencia e é influenciado por essas ondas históricas, difundindo-se com elas. Neste artigo, o objetivo principal foi discutir as origens e a atualidade de quatro grandes linhas de pensamento latino-americanas sobre desenvolvimento - nacional-desenvolvimentismo, revolucionarismo-marxista, neoliberalismo e decolonialismo. A partir disso, fez-se uma breve apresentação de cada uma delas, localizando suas origens e apontando suas principais características e relevância atual. Ao final, foi possível constatar que, apesar da riqueza do debate sobre desenvolvimento na América Latina, é preciso renovar as matrizes antigas e avançar nas novas, diante das limitações que elas apresentam.

Palavras-Chave: América Latina; Desenvolvimento; Pensamento latino-americano.

\section{INTRODUCTION}

There are at least two intrinsic difficulties to study Latin America. The first concerns space, that is, where it begins and where it ends. The second concerns time: how to bring together in a single

\footnotetext{
${ }^{1}$ Este artigo está licenciado sob a Licença Creative Commons Attribution (CC BY 4.0), sendo permitido o compartilhamento com reconhecimento da autoria e publicação inicial nesta revista.

${ }^{2}$ Bacharel em Direito pela Universidade Regional de Blumenau (FURB); Mestre em Relações Internacionais pela Universidade Federal de Santa Catarina (UFSC); Doutorando em Estudos Estratégicos Internacionais pela Universidade Federal do Rio Grande do Sul (UFRGS). Professor nos cursos de Direito e Relações Intenracionais pela Universidade do Vale do Itajaí - UNIVALI. E-mail: ricardo.boff@univali.br. ORCID: https://orcid.org/0000-0002-2818-2825.
} 
field of analysis a region composed of 33 countries $^{3}$ so different from each other? It is not our goal to pursue these discussions in this article. But, for analytical purposes, we follow the ECLAC criterion and consider as Latin American all independent territories located below the border between Mexico and the United States - which excludes, therefore, European possessions such as French Guiana.

On the question of time, there are "waves" of events in history that, although full of exceptions, demonstrate that there are certain conducting wires in the continent's underground, which generate a contagious effect at each period, in which similar phenomena occur in the hole region. Zanatta considers that, even in the face of plurality, there is a principle of unity, founded on the similarities of language and religion, which brings a certain cohesion to Latin America, forging "a system of values that shaped societies and mentalities; in other words, that constitute the deep fabric of a civilization4". (ZANATTA, 2017, p.14).

The development models that prevailed in the region, after the crisis of 1929, produced between the academy, the governmental and the social praxis, are an example of this Latin American civilizational plot. We identified the existence of four historical matrices: the nationaldevelopmentalism, which had more strength between 1930 and 1980; revolutionary-Marxism, which gained momentum with the Cuban Revolution, but lost after the dissolution of the Soviet Union; neoliberalism, which is inspired by the liberal classics and stands out in the 9os; and decolonialism, a current that seeks to question the very idea of development and which took shape in the first decade of the 21st century. All four live together today and compete among them.

In the first section, the importance of ideas in politics, the concept of development, and the reasons why this division into four matrixes were discussed. This was followed by a brief presentation of the "three interpretations" - developmental, Marxist, and liberal, which are inspired by the development paradigm. In the second section, In the second section, we discussed the current nature of these lines of thought in the 21st century. Finally, the third debates the efforts to create a fourth strand, the decolonial one, which questions the development paradigm itself.

The resumption of studies on development in Latin America is important because, although it is an old theme, quite worked on academia, political parties and movements that currently dispute positions of power continue to be guided by these currents of ideas. However, its difficulties and limitations, or even the possible exhaustion of some formulas, require the academy to continue the debate and innovation of ideas. A symptom of the exhaustion of the old models of development and the insufficiency of their renewal, is the search for the so-called outsider leaders in politics, a phenomenon that occurs in several countries in Latin America and around the world. Reviewing the main theoretical currents on development, and presenting the critique of this concept, helps us to open new paths on the road of Latin American thought.

3 According to the Economic Commission for Latin America and the Caribbean (ECLAC).

4 All translations were done by the author of this article. 


\section{DEBATES ON DEVELOPMENT}

To discuss the importance of ideas in the construction of societies and their economic model, we start from Bobbio's definition of "ideology": "systems of political beliefs: a set of ideas and values regarding public order and having the function of guiding collective political behaviors" (BOBBIO, 2003, p. 585). Ideology, according to Eagleton (1997), although complex and involving many meanings 5 , can be defined as a set of beliefs motivated by interests of social groups, which, in some periods of history, become dominant in each society. In other words, there are dominant ideologies, driven by the most powerful groups, but also minority ideologies, which do not assume the same role.

Analyzing classic texts about politics, within the context in which they were written, Skinner (1995) noticed links between theory and practice, with a correlation between speech and action, which reinforce each other. Therefore, thought is always related to the interests of some groups, prevailing, as a tool for political action, the ideas linked to the most influential groups. In this work, we highlight sets of beliefs that, at a given moment in Latin American history, played hegemonic roles in the discussion about development.

In Latin America, following international trends, the idea of development served as a paradigm for political action throughout the twentieth century, and continues to have strength today. In the 19th century, the idea of "progress" prevailed, whose model was the "civilized" nations of Europe, especially the United Kingdom and France. However, the catastrophe of the two world wars, fueled by Fascism and Nazism, and the notion of racial superiority spread in Europe, called this mirage into question. The use of the term "development" was consolidated after the Second World War, as an update of the idea of progress, already in the face of the beginning of the international hegemony of the United States. (SILVA and CHIARELLI, 2018).

The concept of development is based on economic growth. Furtado defines it as the increase in the flow of real income, that is, the "increase in the quantity of goods and services per unit of time available to a certain community" (FURTADO, 1961, p.116). To achieve this increase, it is necessary to discuss the measures that should be taken. In this sense, Santos (2000, p.16) defines development as a set of norms, actions, and values identified with "modern economic rationality".

Like "progress", development also represents a civilizational ideal. Lander (2005) defines it as a model of industrialized society, with patterns of production, consumption, and political organization identical to those of the rich countries of the Western world. Thus, the concept is born as an ideal economic model, with the civilizing mark of the capitalist powers. In this context,

\footnotetext{
5 Among the meanings attributed by Eagleton (1997), are the set of beliefs, values, and ideas that make up the culture of a place; models of reproduction of life in society; a tool for reproducing the interests of certain social groups; guarantee factor for social cohesion; distortion mechanism of reality to create meanings about social facts; maintenance of material structures in the society.
} 
according to Coronil (2005), the "three worlds" division was created: the "first world" was developed, industrialized, and organized in a liberal model; the "second" was the communist, who even though capable of industrial advances, remained politically closed; and the "third" was the underdeveloped, technologically and socially backward.

In the mid-1940s, debates began to grow in Latin American academic and government circles about what would be the ideal way to achieve the longed-for development. At first, the idea of "stages of development ${ }^{6}$ " prevailed, according to which it would be enough for each underdeveloped country to adopt "norms of behavior, attitudes and values identified with modern economic rationality" (SANTOS, 2000, p.16). However, it was just measures copied from rich countries, which ignored the historical, social, and economic peculiarities of others, as well as the relationship patterns between underdeveloped and developed nations. For Lander (2005), the development would be a single road, in a straight line, ignoring the needs and possibilities of different places.

Gradually, Latin America own views on the development emerged, albeit inspired by theories from other continents, whose impetus was given by the production of the Economic Commission for the Development of Latin America and the Caribbean (ECLAC)7. Various classifications exist for the broad theoretical production on development in Latin America. Without pretending to exhaust the topic, we identified a general tendency to divide the theoretical currents into three major groups, although there are countless subdivisions.

The existence of "three interpretations" is synthesized by Bresser-Pereira (2010), who divides them into cepalina, Marxist and dependent-associated. Santos (2000), Martins (2006), and Fiori (2020), despite the addition of some subdivisions ${ }^{8}$, make similar classifications, recognizing the existence of a reformist or structuralist tradition originating from ECLAC; a revolutionary, of Marxist inspiration; and an associated, inspired in the liberal ideas. More precisely, Katz (2016) and Rodrigues (2020) reaffirm the existence of three main lines of Latin American thought on development today: Katz divides them into neoliberalism, socialism, and neodevelopmentism, while Rodrigues writes about "three typologies" and adopts the terms cepalina, Marxist and associated.

In this work, we follow the division of the "three interpretations" or "three typologies". But, to advance the debate, we have included a fourth, which questions the development paradigm itself, which is the decolonial approach. From an analysis of these four interpretations, it is possible to outline scenarios of political thought and practice in Latin America today.

\footnotetext{
${ }^{6}$ The basis of this vision was in the book "Stages of Economic Growth", by Walt Rostov, which established a set of economic measures from which any national state could take a path of development.

7 Created in 1948, ECLAC is linked to the United Nations Development Program (UNDP), based in Santiago, Chile.

8 Martins, although he subdivides, lists the existence of national developmentalism, Marxist theory of dependence and neoliberalism; Santos also subdivides, but lists ECLAC's reformism, the Marxist strands and those associated with foreign capital; Fiori, on the other hand, recognizes the existence of three matrixes, Weberian, structuralist and Marxist, separating the neoliberal from the previous ones, despite their similarities with the Weberian one.
} 


\subsection{NATIONAL DEVELOPMENTAL REFORMISM}

Throughout the 19th century, Latin American elites already discussed the best economic model for achieving "progress". With most of them linked to the primary export activity, the defense of the idea of free trade between nations prevailed, based on the theory of "comparative advantages", by David Ricardo, according to which each country must specialize in what it does best. In the case of Latin America, this meant following the pattern inherited from the colonial period. (PRADO and PELEGRINO, 2016).

However, challenges to this model appeared on the horizon. Inspired by the work of authors like Hamilton, in the United States, and Friedrich List, in Germany, part of the Latin American elites started to defend protectionism and state promotion to promote the industry. Thus, in the 19th century, there was already a debate between "liberals" and "protectionists" in the high circles of power in Latin America. (PRADO and PELEGRINO, 2016; CHANG, 2008)

The "protectionist" field gained momentum and took root only in the 2oth century, after 1948, with the creation of ECLAC. The pioneer and main name of this institution, Raúl Prebisch (1949), after his experience in running the Argentine Central Bank, sought to analyze the specific productive structures of Latin America. Prebisch analyzed Latin American development within the broad framework of capitalism, moving away from traditional views that attributed the problem of underdevelopment only to internal causes (institutional, cultural, racial, etc.). Thus, the author placed the economic condition of Latin America in a context of center-periphery relationship, in which the region is defined by its role in the world economy. According to Rodríguez:

Prebisch does not seek to capture the process of accumulation and technical advancement in a model capitalist economy, considered in isolation, but to elucidate what characteristics this process assumes when the capitalist techniques of production are propagated within the scope of a world economic system composed of centers and periphery. (RODRIGUEZ, 2009, p. 80)

For Prebisch, the Latin American underdevelopment is explained by the "theory of deterioration of the terms of trade", according to which the periphery has a permanent disadvantage in its trade with the center. Central-industrialized countries have technology-intensive production structures, capable of constantly reinventing themselves and adding increasing value to their products. Meanwhile, the periphery, specialized in primary products such as iron, ore, grains, fruits, among others, promotes little production transformation and, in relation to the industrialized product, adds low value. In this way, Prebisch directly attacks the Ricardian idea of comparative advantages. (BIELSCHOWSKY, 2009; GALA, 2010)

In the primary exporting economies of Latin America, islands of productive excellence are accompanied by immense backward areas, where poverty and low productivity predominate. This phenomenon is called "economic duality", or "structural heterogeneity", characterized by the low 
distribution of wages and incomes, endowed with an "army of available labor", and by the low diffusion of technical progress. (BIELSCHOWSKY, 2009; PORCILE, 2010)

Given this situation, it was deduced that it was necessary to industrialize the periphery, to internalize the advantages (or "create comparative advantages"), making its economy more complex, dynamic, and capable of better remuneration. To this end, the State should play a leading role and promote "structural reforms" (FURTADO, 1983), which included the creation of development agencies, exchange control, protectionism, research investment, public investments, incentives to consumption, in addition to income distribution, land reform, educational reform, the adaptation of institutions, among others. In this sense, Fonseca (2013) understands that developmentalism is a polysemic concept, but essentially requires a strategic nation project, the conscious intervention of the State, and industrialization policies.

From the 1930 s to the 1980s, mainly in Brazil, Mexico, and Argentina, but also in other countries, developmental efforts were made and industrialization advanced exponentially. However, it stopped at the insufficiency of the recommended reforms. When promoted with great dependence on capital and foreign technologies, the pressure on the countries' current account remained high, given the high costs of importing machinery, equipment and services, payment of loans, royalties, and remittances of profits. Related to this, social inequality has always remained high, agrarian reform and social policies have progressed erratically, and technological development has been insufficient. (SAMPAIO JR., 2012)

From the Latin American "debt crisis" in the 1980s, which hit industrial development, ECLAC thought lost its breath and its practices were increasingly abandoned by governments. The "neoliberal" theses, which had been developed since the 1970s, come to prevail. According to Bielschowsky (2009), ECLAC sought to adapt to the new times, adopting a greater concern with macroeconomic adjustments, trade opening, "growth with equity", "open regionalism", in addition to themes such as environment and gender. However, the institution has not recovered the importance of the past.

\subsection{THE REVOLUTIONARY MARXIST THEORY OF DEPENDENCE}

From the observation of the limitations of the developmental model, emerged a potent critical current, based on Marxism. Since an industrial-developmentalist leap depended on the existence of a national bourgeoisie that promoted it, its theorists began to identify the limits of that bourgeoisie, given its historical formation and class interests.

The formulators of the Marxist theory of dependence (TMD) shared with the cepalinostructuralists the notions of center and periphery and unequal exchanges. However, when they saw world capitalism as a great cog, composed of interconnected parts that fulfill different functions, they understood that the function relegated to the periphery is necessarily that of supplying raw material 
and underpaid workforce, to enable the enrichment of the center. Therefore, underdevelopment is nothing more than the result of the function of the periphery in the international division of capitalist labor. In the definition of Frank (1980), underdevelopment is the maximum degree of development that a peripheral country can aim for within this system.

So that the bourgeoisie can obtain advantages in this position of dependence, Marini (2000) points out two mechanisms. The first is the "overexploitation of work", according to which the high cost generated by financial, technological, and service dependence, in addition to remittances of profits and the payment of royalties abroad, is compensated by the payment of wages below the line subsistence to workers. This is possible thanks to the existing reserve army of labor in the region, always willing to work narrowly in the face of the need to survive. A second outlet for the bourgeoisie, to guarantee profitability in dependent and industrialized economies, is "sub-imperialism", through which a larger country like Brazil exploits smaller neighboring countries, such as Uruguay, Paraguay, and Bolivia, in the same way that it is explored by central countries9. (MARINI, 2000; PRADO and CASTELLO, 2013)

When observing the behavior of our economic elites, theorists like Marini (2000), Bambirra (1978) and Cueva (1983) realized that, through these compensatory mechanisms, the peripheral elites can take advantage of their positions as lesser members of the elites of imperialist nations such as England and the United States. According to Boron (2014), the permanent efforts of US imperialism to contain any autonomous role in Latin America find support in the local bourgeoisie, which benefits from the mechanism. Therefore, the Latin American bourgeoisie cannot be counted on for structural changes, leaving the workers to promote the only possible way out, which is to break with the capitalist system through the socialist revolution.

This aspect deeply influenced the Latin American left throughout the 2oth century, especially the revolutionary movements, which gained momentum after the Cuban Revolution. However, the dissolution of the Soviet Union and the worldwide decline of communism, including Cuba's economic difficulties, put this aspect in a minority position, in which it remains today.

\section{3. “CONFORMIST LIBERALISM” AND “NEOCONSERVATIVE LIBERALISM”}

The line of dependency theorists was not only characterized by Marxists. Through the work of Fernando Henrique Cardoso, the future president of Brazil, and the Chilean economist Enzo Faletto (1977), the line known as "Weberian theory of dependence" (TWD) emerged. It shares with others the idea of the existence of unequal relations between center and periphery, as part of the functioning of the mechanism of world capitalism, and recognizes the weakness, or lack of interest,

\footnotetext{
9 Thus, through a preferential trade area, or simply taking advantage of physical proximity, a market reserve for industrial products in the smaller countries is created, which will also have the function of supplying the industry in the larger countries with cheap inputs. (PRADO and CASTELLO, 2013)
} 
of our bourgeoisie in overcoming this situation through a "bourgeois revolution". Although it bears some similarities in the diagnosis, it differs profoundly in the prognosis.

Cardoso and Faleto understood that the cost of a socialist revolution, or even of deep reforms, that provoke reactions from the central countries, is very high. The main reason is that, already in the 1970s, the central countries had acquired such technological progress that it would be very difficult, or almost impossible, for peripheral countries to match them. Thus, the path of selfdevelopment, in more autonomous ways, became practically closed. Governments, the authors suggested, should take this fact into account and act according to responsible, non-voluntary ethics. This would mean engaging in regimes led by central countries, adopting their rules and procedures, maintaining the best possible relations with them, and receiving, as a prize for "good behavior", investments and external technology, which would provide Latin America with some degree of development "by association". (SANTOS, 2000)

This view, which we call here "conformist liberalism", in a way returns to the Ricardian division: to focus the economy on what it does best - as a rule, agriculture, and mining - and to open the frontiers for foreign technological excellence, the only possible way of modernization. According to Theotônio dos Santos:

Fernando Henrique had been one of those who demonstrated in 1960 the weakness of the national bourgeoisie and its willingness to become a lesser member of international capital. He was also one of those who observed the historical limit of the national-democratic project and the populism that led it. (SANTOS, 2000, p. 18)

This line of action gained strength in the 1990s, given the crisis of developmentalism and socialism. Latin American countries have adopted, to varying degrees, "neoliberal" reforms characterized by economic, commercial, and financial openness, in addition to privatizations, enshrined in the "Washington Consensus". In foreign relations, the idea of "peripheral realism" arose in Argentina (SCHENONI and ESCUDÉ, 2016), according to which the costs of a foreign policy that imposed challenges or confrontations on the great central powers would be too high, counterproductive, and would tend to internal authoritarianism ${ }^{10}$. Schenoni and Escudé defend the adhesion of weak countries in the periphery to the regimes and institutions of the strongest, within which they could make themselves heard and obtain much greater gains, in view of the costs generated by the way of rebellion. Precisely the government of Carlos Menem, in Argentina, went further in this program.

Neoliberal governments succeeded in combating inflation, but at a very high cost to the State's finances, as they opted for high-interest rates and the attraction of speculative capital. When the external source dried up and the economic crisis hit, the State, dismantled from its structures by

10 The authors cite as examples - skillfully chosen - the difficulties faced by countries such as Cuba, Iran, and North Korea, which have opted for the path of confrontation. 
privatization programs and limited by fiscal adjustment, was unable to respond to social demands (BANDEIRA, 2002).

With the crisis of the liberal belief of "benign globalization", all three interpretations showed their limits, at the arrival of the 21st century. Since then, except for the theoretical innovations of the decolonial line, addressed in the third section, Latin America has been characterized by the attempt to renew the old theoretical matrices.

\section{THE TIMELINESS OF THE "THREE INTERPRETATIONS"}

The three strands presented so far had their peak and their crises in the 2oth century. The developmentalist-cephalin between 1930 and 80, the neoliberal in the 1990s, and the Marxist, as a challenging matrix of the first two, between the Cuban revolution and the end of the Soviet Union. All of them, despite presenting weaknesses difficult to solve, remain disputing the role attributed by Eagleton (1997), of being a set of beliefs and practices capable of influencing the continent's politics. It turns out that none of them currently occupies a dominant position, which leads us to believe that we are experiencing a crisis of paradigms.

The developmentalist line continues to inspire new theoretical attempts to create models of development, such as neo or new-developmentalism. According to Bresser-Pereira (2016), it seeks to modify some aspects of the "old" national-developmentalism, which was characterized by mistaken investments by the State and excessive protectionism in some sectors, which became dependent on that help. Thus, it intends to recover the role of the State as a promoter of the economy, but combining it with the increase of competitiveness and the role of the private sector. To do so, one of its priorities is to overcome the "Dutch disease", linked to the overvaluation of the exchange rate, and to achieve a competitive exchange rate so that the industrial sector can restructure, in addition to maintaining interest rates that aim to encourage productive investments. For Gala, Rocha, and Magacho (2018), structuralist reforms that provide economic complexity are the only way for Latin America to lift itself out of poverty.

According to Katz (2015), Argentina and Brazil, respecting the differences ${ }^{11}$, adopted some aspects of this model. The governments of the Kirchner couple and Lula and Dilma Rousseff sought to offer their "national bourgeoisies" tax advantages and lines of credit for the productive sector. Meanwhile, they encouraged the consumption of the population, providing an environment for growth from the private sector with state support. However, at the end of the commodity boom phase, around 2015 (CORSI, SANTOS and CAMARGO, 2019), in both cases the governments were massively abandoned by the business community, who preferred to bet on liberal solutions

\footnotetext{
${ }^{11}$ While Argentina went deeper into the model, nationalizing companies like the oil company YPF, Brazil took more moderate measures, such as loans via BNDES.
} 
(Maurício Macri and Michel Temer, respectively). Therefore, concludes Katz, the old problem pointed out by dependency theorists, the absence of a national bourgeoisie, not interested or incapable of carrying out a development project, remains current and demonstrates the weakness of any kind of developmentalism. In addition, in the Brazilian case, the Workers Party's governments maintained intact measures considered neoliberal, such as high-interest rates and, under Dilma Rousseff's government, a fiscal adjustment. In addition, the relationship between the State and "national champion" companies has resulted in major corruption scandals, which have placed yet another barrier to popular acceptance of some national development projects.

The Marxist vision has gained momentum again through some governments considered more "radical", among those of the left "pink wave" in the 200os, such as Venezuela, Ecuador, Bolivia, Nicaragua, and Cuba. According to Osório (2015) and Carcanholo (2013), in practice, it is very debatable how much each of them has taken a revolutionary path. There are cases, such as the Venezuelan, in which more progress has been made in the nationalization of private property and the means of production; in others, such as the Bolivian and the Ecuadorian, there is greater proximity to an in-depth development model, through the nationalization of a large part of its mineral resources, but seeking to attract private investors to the country. Even Cuba, which remains firmly revolutionary, gradually opens and moves towards a hybrid model, according to a current jargon in Cuba, "without haste and without pause". Given the transformations and complexities of the current world, it has been a challenge for academics to update the theoretical framework of TMD. As Prado and Castello write:

The multiple determinations of the contemporary stage of Latin American dependent capitalism do not fit in the quotations from the classic formulations of TMD. The continuous transformation of reality impels the new generation of intellectuals to seek an improvement of the Marxist theoretical-methodological framework, an attitude necessary to help in the task of unveiling elements of the appearance and, primarily, of the essence of the development of the capitalist mode of production in these dependent and plundered by the great imperialist corporations, whether external or internal. (PRADO and CASTELLO, 2013, p.15)

However, the calamitous condition of the Venezuelan economy, especially from 2015 onwards, and the precariousness of the Cuban one, contributed to the discredit not only of the "revolutionary" lines, but of the entire field of the left in the continent. While the role of US embargoes in these countries is crucial, "not becoming a Venezuela" has become a catchphrase for the right across Latin America, weakening acceptance of any revolutionary pathway.

The crisis on the left opened the way for the advance of liberal-conservative forces, following a tradition of authors like Campos (1967). It is a combination of neoliberalism with social conservatism, of a religious character, under the banner of defending family values and traditions, contrary to liberal attitudes on issues such as abortion, drugs, and same-sex marriage. The approximation of these groups with the neoliberal belief is linked to their staunch anti-communist 
character, or to the fight against fantasies such as "cultural Marxism", created by these groups to attack their opponents (CASARÕES, 2020). This stance differs, in many cases, from that of the traditional neoliberal parties of the 90s. In Brazil, for example, ex-president Fernando Henrique Cardoso participated in campaigns to legalize marijuana, which would be unimaginable to happen with the current state-head Jair Bolsonaro. Colombia, Paraguay, and Guatemala are other examples of countries whose neo-conservative wave has gained momentum in politics. A more liberal right, with fewer or scarce appeals to conservative ideals, is found, for example, in Uruguay, with President Lacalle Pou.

Neoliberal revenues, from opening and betting on the flow of foreign capital, can repeat the weakness of the nineties, which is to leave economies more exposed to capital flight and investments in any international crisis while dismantling social protection. The government of Maurício Macri, in Argentina, as well as the brief experience of Jeanine Añez, in Bolivia, were not successful in this reformulation, giving way to his opponents. In Chile, which for years has been cited as a model of pro-market organization, the poor results of the privatization policies on transportation, social security, health, and education services, have resulted in turmoil and protests the impractical cost of living and in the call for a new constituent. In the case of more radical conservative versions, such as Brazil and Colombia, the movement may weaken if the "enemies", real and imagined, lose strength, or cause less "fear" in the population.

The advance of this right shows signs that it will not be hegemonic. The electoral victories of the Peronist Alberto Fernandez, in Argentina, and the candidate of Movimiento al Socialismo, Lucho Arce, in Bolivia, as well as the "late" victory of the left in Mexico, with Andres Manuel Lopes Obrador, point to a politically divided continent.

\section{DECOLONIALISM AND POST-DEVELOPMENTALISM}

What do all the previous lines have in common? The development myth as a search horizon. All of them are concerned with overcoming underdevelopment and are debating on the best way to develop. Whether through greater state intervention, via the revolution of the proletariat or by faith in the free market, none of these aspects question whether developing is really the best option.

In the 1990s, a group of Latin American thinkers called "modernity-coloniality" (BALLESTRIN, 2013), in the wake of post-colonial thinking by authors such as Frantz Fanon and Edward Said, questioned the very pillars of modernity on which notions were based as "progress" and "development". For them, modernity is a period of history, beginning with the conquest of what would be called "Latin America", from which Europe placed itself at the center of the world. Gradually, Europeans began to centralize control over material production, trade chains, workforce, and knowledge production. To make it possible, it was necessary to "subordinate" other peoples, 
creating successive narratives that justified their superiority. For Quijano (2005), the first criterion for this differentiation between "superior" and "inferior", "dominant" and "dominated" peoples, was the color of their skin. In other words, European white saw itself as superior to black, brown, or yellow. From then on, different dualities would continue to fulfill this role, such as "faithful / infidels", "civilized / barbarians" and, today, "developed / underdeveloped". Thus, the control of culture and the production of knowledge is tied, in modernity, to the control of work and material production.

However, this domain can only be exercised through what Dussel (1992) calls "covering up the other", that is, the subordination of visions, knowledge, theories, or worldviews, produced outside the Eurocentric matrix (displaced to the United States, in the twentieth century). Therefore, modes of production, social organization, cultural practices, and worldviews outside the dominant matrix are considered heretics, uncivilized, backward, archaic, or any adjective that diminishes them. It is against this Eurocentric and prejudiced modernity that the "decolonial" movement is rising, seeking to put back on the agenda ways of seeing the world and producing knowledge based on other pillars. (GUDYNAS, 2011, QUIJANO, 2014)

This is what social and intellectual movements do, for example, with roots and influence in the Andean world, by valuing principles such as "buen vivir / bien vivir", used by the ancient peoples of that region. There is extensive production on its meaning, but we can highlight, according to Quijano (2014) and Acosta (2014), a collectivist ethic that values local traditions, including political organization and justice; a relationship with nature that does not consider it a mere product to be explored, but a living being worthy of rights, which makes up a totality in harmony with the human being; an ethics, in short, that denies the exploitation of the work of other human beings and nature, because it values life for its own existence, and not for its economic value.

These prepositions, to some extent, are present in the Constitutions of Bolivia and Ecuador, which were re-founded as "Plurinational States" (SCHALVEZON, 2015), where each nation, by linguistic and cultural criteria, is endowed with a certain autonomy to manage its way of life and production according to its principles, as the bien / buen vivir. However, there are immense difficulties in putting these innovations into practice, which many already call pachamamist utopia.

First, there is a certain inaccuracy in the meaning of "buen vivir / bien vivir", looking like a wide letter of intentions that still need elaboration. In addition, these principles are not accompanied by a model of social and economic organization that addresses the material needs of the population. According to Schalvezon (2015), one of the main clashes that occurred in Bolivia and Ecuador is precisely in the dilemma between buen vivir / bien vivir and the need to grow economically. After all, in predominantly primary-exporting countries, improving living conditions involves the extraction of primary resources, which clashes head-on with local autonomies and the view of pachamama (mother-earth) as a living being, whose existence must be harmonious with humans. The conflicts between "local people" and "central governments" (MIGNOLO, 2003) are many, in 
both countries, which has undermined the indigenous support base of the governments of Evo Morález and Rafael Correa. In Ecuador, the break was so strong that it contributed to the victory, in 2021, of the right-wing candidate Guillermo Lasso. Furthermore, in Europeanized and hypermodern metropolitan regions, such as Buenos Aires, Montevideo, and São Paulo, it is more difficult to imagine this type of thinking going beyond small academic circles. Because of this complexity, Quijano admits that it is an open proposal: "In other terms, the new horizon of historical meaning emerges with all its historical / structural heterogeneity. In this perspective, Bien's proposal to live is, necessarily, an open historical survey that requires to be continually asked, debated and practiced". (QUIJANO, 2014, p. 33)

The decolonial line, when proposing alternatives, suffers immense difficulties in the face of the lack of concrete proposals elaborated at the time of offering, even to the Andean peoples, an economic model that guarantees material well-being, while respecting ancestral principles. But it has the merit of offering a powerful and necessary critique of modern Eurocentrism and the evils of development, which the traditional "three interpretations" are not capable of resolving.

\section{FINAL CONSIDERATIONS}

Latin America, despite the tendency to seek ideas and solutions to its problems in Europe and the United States, has a long trajectory of its own thinking. Here, we identified four general lines of theorization that indicate paths to Latin American development, or to overcome the notion of development. The first three have already reached their peak and demonstrated their weaknesses, but they are still important and seeking to update themselves. The latter, although innovative, lacks structural weaknesses in its implementation.

The old national developmentalism provided a great modernizing leap for the countries of the region, many of them going from being just primary exporting economies to creating considerable industrial parks. However, it also left a mark of public debt, excessive state protectionism, artificial maintenance of uncompetitive companies and contributed to an inflationary crisis in the "lost decade" of the eighties. Neodevelopmentism seeks to renew itself and correct its weaknesses, keeping the idea of supporting the industry with its technological domain, through an economic approach practiced in a symbiosis between the State and the private sector. But it comes up against structural deficiencies in technology, productivity, and internal savings, in addition to the lack of interest of the "bourgeoisie", increasingly internationalized, in some national or regional development projects. In the face of a financialized capitalism, as well as Asian competition, any project focused on national or regional production becomes even more difficult.

The Marxist-revolutionary line, critical of the weakness and / or disinterest of the Latin American bourgeoisie, never regained its prestige with the collapse of the Soviet Union. Cuba's 
suffered resistance, full of material shortages, in addition to Venezuela's complications through the revolutionary route, lend even more wear and tear to proposals of revolution or socialism. Still, the neoconservative wave has as its preferred enemy, real or imagined, communism and its infamous "Foro de São Paulo12". Despite this, dependency theorists have sought to update the Marxist version, transforming it into a "museum of great news ${ }^{13}$ ", capable of criticizing the economic dependency of the region. However, revolutionaries will have a long way to convince the masses to join their project, in a context of work precariousness, dispersion of proletarians, and weakness of labor unions, in an increasingly "uberized" economy. There is also the herculean challenge of dragging wide sectors of the amorphous "middle class" into a socialist adventure, in the face of so many bad examples that the applied model has left behind.

Liberals gained strength in the 1990s. They applied their neoliberal agenda, including privatization, commercial and financial opening, regulatory agencies, reducing the State to a minimum, and limiting public spending. But this model, in societies as unequal as those in Latin America, where many people depend on public policies, resulted in an economic and social crisis that brought the left to power. However, in the face of the failure, or wear, of the governments of the left "pink wave", neoliberalism had its return (or, in cases like Brazil, its relative continuity), in association with conservative social forces. However, the old-new neoliberal formula can repeat its failures of the 1990 s and be short-lived, which has already been observed in Argentina and Bolivia, in addition to the ongoing transformations in the Chilean state.

Finally, the innovative "decolonial" line seems to be skating in the absence of an economic model that balances the desires for material gains of its population, with its institutional architecture and innovative constitutional principles. As was clear from the experiences in Bolivia and Ecuador, there are "clashes of worlds ${ }^{14}$ " between central and plurinational states, or between extractivism and buen vivir.

The expression "museum of great news" seems to fit well with the traditional lines of Latin American thought, be it "neodevelopmentism", "neo-revolutionism" or "neoliberalism". All of them struggle to update themselves, as a set of ideas and practices that guide political action, but none of them manage to get rid of their limitations and contradictions demonstrated throughout the 2oth century. Decolonialism, the only new idea, still suffers from structural weaknesses and contradictions in its practices.

We can conclude in two ways. The pessimist is that Latin American thought has been spinning in circles, while its dependent economy has not moved and its societies remain the most

\footnotetext{
12 Organization of Latin America leftist parties that takes place in São Paulo since 1990, used by right-wing movements as another "proof" of communists advancing in the region.

${ }^{13}$ Expression taken from the event "Dependency in Latin America: a museum of great news", carried out by the Research and Training Center of SESC São Paulo in 2017.

${ }_{14}$ Expression borrowed from the Peruvian documentary "Choque de Dois Mundos", which presents a dispute between indigenous Amazonian populations and the government over the extraction of oil.
} 
unequal in the world. The optimistic one is that starting from the wealth of ideas that Latin American scholars and leaders have already built, there is a lot of work and space for theoretical and practical innovations in the discussion about development, either to obtain it or to replace it with a better paradigm.

*Artigo recebido em 02 de dezembro de 2020, aprovado em 25 de maio de 2021.

\section{REFERENCES}

ACOSTA, Alberto. Bem Viver: uma Oportunidade para Imaginar Outros Mundos. São Paulo: Autonomia Literária, 2014.

BALLESTRIN, Luciana. América Latina e o giro decolonial. Revista Brasileira de Ciência Política, n.11. Brasília, p. 89-117, mai/ago 2013.

BAMBIRRA, Vânia. Teoría de la dependencia: una anticrítica. México: Era, 1978.

BANDEIRA, Luiz Alberto Moniz. As políticas neoliberais e a crise na América do Sul. Rev. bras. polít. int., Brasília, v. 45, n. 2, p. 135-146, Dec. 2002.

BIELSCHOWSKY, Ricardo. Sesenta años de la CEPAL: estructuralismo y neoestructuralismo. In: Revista CEPAL n. 97, abr. 2009.

BOBBIO, Norberto. Dicionário de Política. Brasília: Editora UNB, 2003

BORON, Atilio. América Latina en la geopolítica del Imperialismo. Buenos Aires: Ediciones Luxemburg, 2014.

BRESSER-PEREIRA, Luiz Carlos. As três interpretações da dependência. Perspectivas, São Paulo, v. 38, p.17-48, jul./dez. 2010.

BRESSER-PEREIRA, Luiz Carlos. Teoria novo-desenvolvimentista: uma síntese. Cadernos do Desenvolvimento, Rio de Janeiro, v. 11, n. 19, pp.145-165, jul./dez. 2016.

CAMPOS, Roberto. Reflections on Latin American Development. Austin: University of Texas Press, 1967.

CARCANHOLO, Marcelo. O atual resgate crítico da teoria marxista da dependência. D. Trab. Educ. Saúde, Rio de Janeiro, v. 11 n. 1, p. 191-205, jan./abr. 2013.

CARDOSO, Fernando H. e FALETTO, Enzo. Dependência e desenvolvimento na América Latina: Ensaio de Interpretação Sociológica. Quarta Edição. Rio de Janeiro: Zahar Editores, 1977.

CASARÕES, Guilherme. The First Year of Bolsonaro's Foreign Policy. In: MORI, Antonella; MAGRI, Paolo. Latin America and the new global order: Dangers and Opportunities in a Multipolar World. Milão: ISPI, 2020. 
CHANG, Ha-Joon. Bad Samaritans: The Myth of Free Trade and the Secret History of Capitalism. New York: Bloomsbury Press, 2008.

CORONIL, Fernando. Natureza do pós-colonialismo: do eurocentrismo ao globocentrismo. LANDER, Edgardo (Org.). A Colonialidade do Saber: eurocentrismo e ciências sociais. Perspectivas latino-americanas. Buenos Aires: CLACSO, 2005

CORSI, Francisco Luiz; SANTOS, Agnaldo; CAMARGO, José Marangoni. A América Latina: ciclo de commodities e crise do capitalismo global. Austral: Revista Brasileira de Estratégia e Relações Internacionais, v.8, n.15, Jan./Jun. 2019, p.168-194

CUEVA, Augustín. O desenvolvimento do capitalismo na América Latina. São Paulo, Global Editoras: 1983.

DUSSEL, Enrique. 1492. O encobrimento do outro. A origem do mito a modernidade. São Paulo: Vozes, 1992.

EAGLETON, Terry. Ideologia. Uma Introdução. São Paulo; UNESP/Boitempo, 1997.

FIORI, Jose Luiz. Estado e desenvolvimento na América Latina contemporânea. Revista de Economia Contemporânea, vol. 24, n. 1, p. 1-23, 2020.

FONSECA, Pedro Cezar Dutra. Desenvolvimentismo: a construção do conceito. Textos para discussão. IPEA, 2013.

FRANK, André Gunder. Acumulação Dependente e Subdesenvolvimento: repensando a teoria da dependência. São Paulo: Brasiliense, 1980

FURTADO, Celso. Desenvolvimento e subdesenvolvimento. Rio de Janeiro: Fundo de Cultura, 1961.

FURTADO, Celso. Teoria e política do desenvolvimento econômico. São Paulo: Abril Cultura, 1983.

GALA, Paulo. Macroeconomia estruturalista do desenvolvimento. Revista de Economia Política, v. 30, n. 4, p. 663-680, 2010.

GALA, Paulo, ROCHA, Igor, MAGACHO, Guilherme. The Structuralist Revenge: economic complexity as an important dimension to evaluate growth and development. Brazil. J. Polit. Econ. vol.38, n. 2, São Paulo, abr/jun 2018.

GUDYNAS, Eduardo. Desarrollo, extractivismo y Buen Vivir. In: Más allá del desarrollo, Grupo Permanente de Trabajo sobre Alternativas al Desarrollo, Abya-Yala, Fundación Luxemburgo, Quito: 2011.

KATZ, Claudio. Neoliberalismo, Neodesenvolvimentismo, Socialismo. São Paulo: Expressão Popular, 2016.

KATZ, Claudio. ¿Qué es el neodesarrollismo? Una visión crítica. Argentina y Brasil. Serv. Soc. Soc., São Paulo, n. 122, p. 224-249, abr./jun. 2015

LANDER, Edgardo. Ciências sociais: saberes coloniais e eurocêntricos. LANDER, Edgardo (Org.). A Colonialidade do Saber: eurocentrismo e ciências sociais. Perspectivas latino-americanas. Buenos Aires: CLACSO, 2005

MARINI, Ruy Mauro. Dialética da dependência. Petrópolis: Vozes, 2000. 
MARTINS, Carlos E. O pensamento latino-americano e o sistema mundial. LEVY, Bettina (comp.). Crítica y teoria en el pensamento social latinoamericano. Buenos Aires: CLACSO, 2006.

MIGNOLO, Walter. Histórias locais/projetos globais. Colonialidade, saberes subalternos e pensamento liminar. Trad. Solange Ribeiro de Oliveira. Belo Horizonte, Editora UFMG: 2003.

OSÓRIO, Jaime. América Latina en la valorización mundial del capital. Revista da Sociedade Brasileira de Economia Política, vol. 41, jun./set. 2015.

PRADO, Fernando C. e CASTELO, Rodrigo. O início do fim? Notas sobre a teoria marxista da dependência no Brasil contemporâneo. Revista Pensata, v. 3, n. 1, nov. 2013.

PRADO, Maria L. e PELEGRINO, 2016 Gabriela. História da América Latina. São Paulo: Editora Contexto: 2016.

PORCILE, Gabriel. Heterogeneidade estrutural: conceito e evidências na América Latina. Economia \& Tecnologia, Ano 06, Vol. 21, Abr./Jun. 2010.

QUIJANO, Aníbal. Colonialidade do poder, eurocentrismo e América Latina. LANDER, Edgardo (Org.). A Colonialidade do Saber: eurocentrismo e ciências sociais. Perspectivas latinoamericanas. Buenos Aires: CLACSO, 2005

QUIJANO, Aníbal. "Bien vivir": entre el "desarrollo" y la des/colonialidad del poder. In: Des/colonialidad y bien vivir. Un nuevo debate en América Latina. Lima: Editorial Universitaria, 2014.

PREBISCH, Raúl. El desarrollo economico de la America Latina y algunos de sus principales problemas. Santiago de Chile, Comision Economica para America Latina y el Caribe (CEPAL), 1949.

RODRIGUES, Bernardo Salgado. As três tipologias políticas do desenvolvimentodependente na América Latina: contribuições para um debate contemporâneo. REBELA, v.10, n.2., p. 207-232, mai./ago. 2020.

RODRIGUEZ, Octavio. O estruturalismo latino-americano. Rio de Janeiro: Civilização Brasileira, 2009.

SAMPAIO JR., Plínio de Arruda. Desenvolvimentismo e neodesenvolvimentismo: tragédia e farsa. Serv. Soc. Soc., São Paulo, n. 112, p. 672-688, Dec. 2012.

SANTOS, Theotônio dos. A teoria da dependência: um balanço histórico e teórico. Rio de Janeiro: Civilização Brasileira, 2000.

SCHALVEZON, Salvador. Plurinacionalidad y Vivir Bien/Buen Vivir: Dos conceptos leídos desde Bolivia y Ecuador post-constituyentes. Ediciones Abya Yala: Quito, 2015.

SCHENONI, Luis e ESCUDÉ, Carlos. Peripheral Realism Revisited. Rev. Bras. Polít. Int., v. 59, n.1, p.1-18, 2016.

SILVA, Sidney R. e CHIARELLI, Alexandre. Crítica à ideia de progresso na perspectiva do bem-viver. VI Congresso de Desenvolvimento Social. Desafios à democracia, desenvolvimento e bem-comum. 14 a 16 de Agosto de 2018.

SKINNER, Quentin. As fundações do pensamento político moderno. São Paulo: Companhia das Letras, 1995. 
ZANATTA, Loris. Uma breve história da América Latina. São Paulo: Cultrix, 2017. 